\title{
Understanding the use of interactive whiteboards in primary science
}

Trudy Sweeney

Flinders University, Australia

\begin{abstract}
This paper explores the dimensions of change experienced by a specialist primary science teacher in Australia as she attempted to embed an interactive whiteboard into her practice as a tool to enhance interactive teaching and learning. This paper uses the theoretical frameworks of activity theory and the stages of concern to understand the behavioural and affective dimensions of change related to the use of interactive whiteboards in primary science. It is argued that the identification and resolution of tensions and concerns in teachers' practice is crucial to maximise the potential of interactive whiteboards to enhance learning interactions in a shared dialogic space.
\end{abstract}

\section{Introduction}

At the end of 2009, 31\% of Australian classrooms were equipped with interactive whiteboards (IWBs) (Lee, 2010). Until the last five years, there was limited Australian research into the use of IWBs (Schuck $\&$ Kearney, 2007). One of the largest early trials of their use was undertaken at Richardson Primary School in the Australian Capital Territory (Kent 2004, Lee \& Boyle, 2003) which described how the IWB acted as a conduit for teachers to integrate information and communication technology (ICT) resources in their e-teaching. More recently, the body of Australian IWB research has increased and concentrated on how they are being used by teachers (Bennett \& Lockyer, 2008, Schuck \& Kerney, 2007). Recent Australian IWB research topics include: appropriate pedagogical strategies (Northcote, Mildenhall, Marshall, \& Swan, 2010; Winzenried, Dalgarno, \& Tinkler, 2010), the importance of pre- and in-service teacher training (Holmes, 2009; Campbell \& Kent, 2010; Divaharan \& Koh, 2010; Jones \& Vincent, 2010; Lai, 2010), the use of digital resources (Maher, Phelps, Urane, \& Lee, 2012), effective interactive pedagogies in science education (Murcia \& Sheffield, 2010), mathematics education (Zevenbergen \& Lerman, 2008; Swan \& Marshall, 2010), networked collaboration among educational providers (Dawson, 2010; Mitchell, Hunter, \& Mockler, 2010; Yelas \& Engles, 2010), major tensions associated with pedagogical change (Sweeney, 2010); and the use of multimodal texts in English (Kitson, 2011).

International research suggests that IWBs can have positive effects on both teaching and learning (Smith, Higgins, Wall, \& Miller, 2005). They are well adapted to whole-class teaching, particularly in terms of enlivening formal expositions, including demonstrations of practical procedures and explanations of complex concepts (Somekh, 2007). IWBs can facilitate the emergence of new digital pedagogic practices which can support teachers' lesson planning using an invisible 'script' which enables them to "multi-task in new ways" by releasing "more of their mental capacity to make observational assessments for learning during whole class teaching" (Lewin, Somekh, \& Steadman, 2008, p. 99). Recently, researchers have begun to focus on the potential of IWBs to promote interactive and collaborative learning environments (Gillen, Staarman, Littleton, Mercer, \& Twiner, 2007; Mildenhall, Swan, Northcote, \& Marshall, 2008). IWBs can focus students' attention and communication on the external representations of thinking on the large screen and hence support productive talk and learning (Kershner, Mercer, Warwick, \& Staarman, 2010). They can also offer support for students to work semi-autonomously on learning tasks by helping them to consider "alternative possibilities as a group, externalising thinking on the screen, referring to existing knowledge in available screens, and providing 'online' contingent guidance and support in real time (without the teacher's physical presence)" (Kershner et al., 2010, p. 380).

Despite their potential, many of the envisaged benefits of IWBs are not always realised (Gobbo \& Girardi, 2001) and the research results reveal "a very mixed picture" (Rudd, 2007, p. 2). Indeed, it is possible to reinforce any manner of educational approaches (Green, Facer, Rudd, Dillon, \& Humphreys, 2005) and they can reinforce familiar patterns of teacher-student interaction in whole class teaching (Smith et al., 2005; Underwood, et al., 2010). Kennewell, Tanner, Jones, and Beauchamp (2008) have suggested that the advent of the IWB may even be considered to be "a backward step that gives a new impetus to traditional, teacher-centred, approaches" associated with a high level of teacher control (p. 71). 
Similarly, Zevenbergen and Lerman (2007) concluded, "the technologically impressive features of the IWB can lead to it being used to close down further the possibility of rich communications and interactions in the classroom" (p. 861).

There is substantial research literature (current and in the last decade) that expresses concern that the use of IWBs can sometimes cause a reversal in teacher pedagogy associated with a reduction in student use of the IWB and increased teacher dependence, even if the teacher concerned taught previously in a studentcentred manner (Vincent \& Jones, 2008). However, current research suggests a change in this trend. This corresponds with a shift away from IWB research focused on teacher-led sessions and the nature of the interaction between the teacher and student at the IWB (Kershner et al., 2010), towards a focus on students' communication and thinking during their semi-autonomous use of the IWB during collaborative group work (Warwick, Mercer, Kerschner, \& Kleine Staarman, 2010; Murcia \& Sheffield, 2010). In addition, research suggests that non-expert peer mentoring professional development models are highly effective in helping teachers develop modified teaching behaviours to exploit the affordances of the technology (Jones \& Vincent, 2010).

A major factor influencing how teachers use the IWB relates to how they perceive the affordances of the tool for the activity in question (Warwick, et al., 2010). Importantly, the affordances perceived appear directly related to the teacher's pedagogic understandings and intentions (John \& Sutherland, 2005). The introduction of new technologies has not usually been accompanied by adequate understanding of the implications for pedagogy (Hennessy, 2006). The development of teachers' skills and knowledge using IWBs is critical to their effective use (Higgins, Beauchamp, \& Miller, 2007). Teachers require a significant amount of sustained experience to become technically and pedagogically accomplished in using IWBs (Beauchamp, 2004; Glover \& Miller, 2001; Levy, 2002). Teachers need advice and support to make choices about how and when to use IWBs based on pedagogical content knowledge, combined with the process of pedagogical reasoning (Kennewell et al., 2005). Lewin et al. (2008) make the point that if IWBs are used "as glorified blackboards, or as occasionally animated passive whiteboards, then there will be limited effect on pupils' learning" (p. 297). In addition, they maintain that:

It is clear that while teachers carry the onus of deciding appropriate modalities and content, they need to allow pupils to interact with the IWB in ways that permit it to function as the main mediating artefact. Both literally and metaphorically teachers have to learn to 'stand away' and allow pupils to fully engage in interaction with what the IWB presents (p. 297).

In Australia where there is a clear policy concern with the development of inquiry-oriented and constructivist-based science learning at the primary level, many teachers are developing a commitment to the use of new technologies as an important and integral part of science pedagogical reform (Hackling, Peers, \& Prain, 2007; Australian Academy of Science, 2012a) and the implementation of the Science learning area and the ICT General Capability of the new Australian Curriculum (ACARA, 2012). Research suggests that the IWB can make some identifiable contributions to student's productive communication and thinking in primary school science (Kershner et al., 2010). In particular, the technology, the learning task and the teacher support can be merged to "provide both a tool and an environment that can encourage the creation of a shared dialogic space within which co-constructed knowledge building can take place" (Warwick et al., 2010, p. 350). It is argued that engaging students shared exploratory talk and substantive conversations, contributes to their development of scientific literacy (Murcia \& Sheffield, 2010).

Research suggests that teachers' use of new technologies progresses along predictable patterns of development. During the early stages of development, as teachers are learning to deal with concerns related to efficiency, organisation, managing, scheduling and time demands, the technology is applied to old tasks (Naisbitt, 1984) such as the creation and delivery of information and skills (Illinois Institute of Design, 2007). At this time, teachers' efforts tend to focus on short-term use of the technology with little time for reflection (Hall \& Hord, 2006) and technology is often used to reinforce lower cognitive skill development related to the content under investigation (Moersch, 2011). Later, once teachers are competent and reliant upon the new technology, they become receptive to changing their techniques and modifying its use as a pedagogical tool to improve student learning (Glover, Miller, Averis, \& Door, 2007; Hall \& Hord, 2006). At this level, teachers use technology tools and resources to promote higher order thinking, engage student learning and support authentic assessment practices in the classroom 
(Moersch, 2011). Thus, the research literature points to a progression from technology to pedagogy (Glover et al., 2007).

According to Hooper and Rieber (1995), many teachers are unable to realise the potential benefits of using technology because they fail to 'break through,' a critical 'Integration' phase. This 'break through' is only possible if teachers see their role as supporting and facilitating students to construct and shape their own knowledge using the technology. Thus, teachers must be able to draw together contemporary understandings of technology, pedagogy and content knowledge (Mishra \& Koehler, 2006; Jang, 2010). There is some evidence that IWBs may support primary science teachers to develop this knowledge (Jang \& Tsai, 2012). Hooper and Rieber argue that a failure to 'break through' the 'Integration' phase results in the technology being misused or discarded with a likely result a return to the status quo. One example of the misuse of IWBs is when teachers are reluctant to deviate from their prepared lesson presentations using native IWB software to respond to students' needs (Zevenbergen \& Lerman, 2007). This can cause frustration among students who prefer to participate actively in the learning process and physically interact with the IWB. The use of the IWB in this way "militates against any pedagogic shift towards greater intellectual challenge" (p. 861).

This paper aims to identify the major tensions and concerns of one specialist teacher as she attempted to use an IWB to enhance teaching and learning of primary science. The theoretical frameworks of activity theory (Cole \& Engström, 1993) and the stages of concern (Hall \& Hord, 2006) are used to investigate the dialectical process by which teachers' consciousness and professional learning and development simultaneously shape and are shaped by the uptake and use of IWBs (Gay, Rieger, \& Bennington, 2002). It is argued that the identification and resolution of tensions and concerns in teachers' practice is crucial to maximise the potential of interactive whiteboards.

\section{Activity theory and stages of concern}

This paper used the theoretical frameworks of activity theory and the stages of concern to investigate one case study. The main unit of analysis in activity theory is the activity system. A model of the second generation activity system is represented in Figure 1.

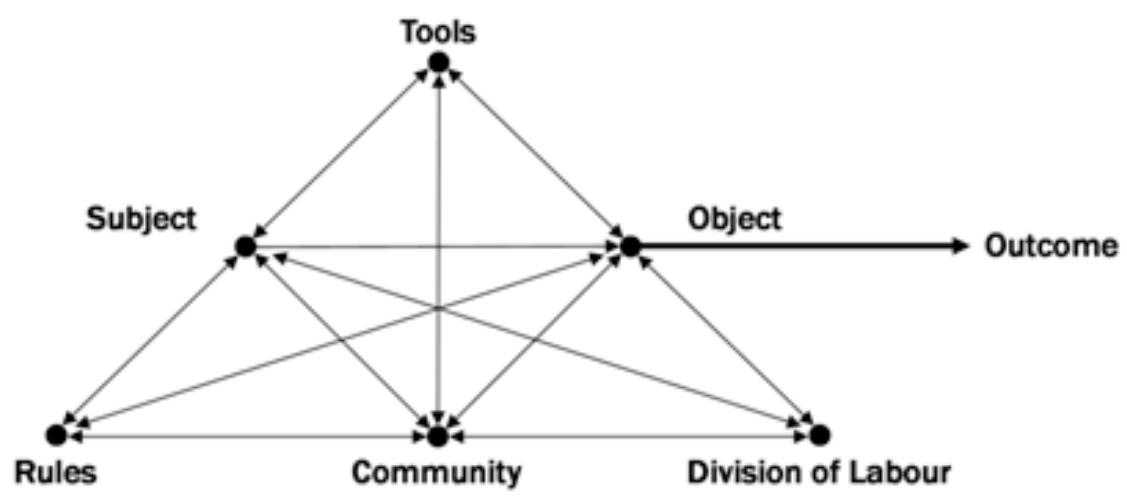

Figure 1. Second generation activity system (Cole \& Engestrom, 1993).

The subject node refers to the individual or group whose agency or point of view is taken in the analysis of the activity. The activity of the subject is directed towards the object node or goal and is transformed into outcomes with the help of physical and symbolic external and internal tools which mediate the into an outcome (Engestrom, 1993). Thus, the object embodies the meaning, motive and purpose of the system. The base of the triangle represents the contextual characteristics of the activity system. The community node refers to the participants who share the same general object with the subject. The division of labour node refers to how tasks are divided between community members (horizontally as well as the vertical division of power and status). Rules are explicit or implicit regulations, norms and conventions that constrain actions and interactions within the activity system (Centre for Activity Theory and Developmental Work Research, 2003). 
The stages of concern provides a helpful construct to monitor, describe and quantify the emotional part of change that is often neglected, with resulting arousal of unnecessary resistance to an innovation (Hall, 2010). "There is a long history of research and application of this construct and its measures" (Hall, 2010) based on the original work by (Fuller, 1969). The stages of concern describe a predictable pattern of developmental stages that teachers move through as they become increasingly sophisticated and skilled in using new innovations. The seven stages are: (0) awareness, (1) informational, (2) personal, (3) management, (4) consequence, (5) collaboration, and (6) refocusing (Hall \& Hord, 2006). The first stage, typifies little concern or involvement in an innovation. The second and third stages are described as "self" types of concerns that focus on teachers' personal feelings of uncertainty and a need to find out more about the innovation such as its general characteristics, effects and demands. The fourth stage is "task" oriented, where attention is focused on the processes and tasks of using the innovation and issues related to efficiency, organisation, management and time. The last three stages are "impact" kinds of concerns that deal with teachers' external concerns about how the innovation may affect students, colleagues, and future work. At this final stage, individuals have definite ideas about major changes or powerful alternatives to the existing form of the innovation (Hall \& Hord, 2006; Hall, 2010). It is noteworthy that progress through the stages is not guaranteed and is not necessarily in one direction.

\section{Method}

This study forms part of a larger project that investigated the impact of IWBs on teachers' pedagogy in one Australian primary school over an eighteen-month period involving eight participants. Data were collected using a series of three individual interviews, two videotaped classroom observations, a pair interview and two group interviews. A single researcher, with the informed consent of management, the research participants, students and their parents, carried out the research at predetermined times. The initial data collection was undertaken with an individual interview in Term 3 and a fifty-minute video case study in Term 4 of the same year. The aim of these activities was to establish rapport and trust with participants, gain an insight into their previous experiences, pedagogical beliefs and values and their perspectives and practices associated with their use of the IWB and other technologies in their classroom. During the next 12-months the researcher had regular contact with participants (at least once each term) during which two further individual interviews, two group interviews and a pair interview took place. A second video case study was conducted at the end of the eighteen-month period in December. The purpose of the pair and group interviews was to facilitate shared dialogue between participants and the researcher focused on the use of the IWB and the identification of concerns, tensions and issues. These opportunities were used to explore and validate the emergence of research themes and encourage participants to provide non-expert peer support to resolve shared problems.

The purpose of the video-taped case-studies was to provide opportunities for participants to reflect, evaluate and share their practice using the New South Wales model of pedagogy called the Quality Teaching Framework (State of NSW, 2003). This framework identifies eighteen elements of effective pedagogy divided into the three dimensions of 'intellectual quality', 'quality learning environments' and 'significance'. During this project, teachers participating in this study took part in a one-day professional learning day to learn how to apply the framework. During the study close attention was given to analyse how the elements of effective pedagogy were demonstrated or could be incorporated into the description of indicators to promote quality interactions using the interactive whiteboard. For example, the higher levels of the continuum include sustained interactions, higher-order thinking, strong connections between learning within and outside of the classroom, and meaningful connections between subject areas. The Quality Teaching Framework is generic to all year levels, subjects and contexts and does not refer to the use of interactive whiteboards or science. Research suggests that IWBs allow "many elements of the Quality Teaching Framework to be realised" (Schuck \& Kearney, 2007, p. 25).

All interviews were semi-structured, transcribed and verified by participants. This methodology acknowledged participants as the critical agents in mediating the integration of the IWB into their "pedagogical subject knowledge" (Beauchamp, 2006) and explored their use of it to promote quality interactions and interactivity (Armstrong, Barnes, Sutherland, Curran, Mills, \& Thompson, 2005, p. 457). Data were coded using NVivo ${ }^{\mathrm{TM}}$ qualitative software (QSR International, 2008) using a grounded theory approach (Strauss \& Corbin, 1998) to support themes to emerge throughout the study. Data analysis was a cyclic process involving nodes related to both activity theory (Engestrom, 1987) and the stages of concern (Hall \& Hord, 2006). Activity theory supported the identification of attempts to change behaviour in the 
activity systems, whilst the stages of concern provided a way to monitor, describe and quantify the affective aspects of change related to the use of interactive whiteboards as an innovation.

The stages of concern and activity theory lenses are used together in the following discussion of the case to understand and describe the participant's concerns and theorise her attempts to change her teaching practice to integrate the use of IWBs into specialist primary science lessons.

\section{Theoretical analysis and discussion}

Jenny, a specialist science teacher at Kingsford Primary School (pseudonym) had been the school's Reception to Year 7 science specialist teacher for 2 years. In South Australia, students commence school at age five years old in a Reception class and graduate to secondary school after they have completed Year 7 (around age 12 years). Specialist teachers such as Jenny provide regular classroom teachers with 'non-instructional time' release from teaching duties with their particular class of students to support curriculum planning and preparation. It is uncommon to have primary science specialist teachers in South Australian schools, as often, other specialist teachers are appointed in learning areas such as physical education, visual arts and drama and/or languages.

Jenny had been teaching for 21 years during which time she had spent most of her time as a regular classroom teacher for Year 3-7 students. She had taught in the country, teaching Year 9 and 10 Science and also had experience as a specialist art and science teacher. At the commencement of the study, Jenny had been using an IWB for 12-months. This had been purchased as a result of her being awarded a state SCIMAS (Science and Mathematics) grant of $\$ 5000$ to develop an inquiry-learning unit for students, conduct an action research project and present her findings to her peers. The aim of Jenny's project was to identify and use online resources to visually enhance the representation of scientific concepts to promote students' understanding using an IWB. Unfortunately, due to a significant delay in the purchase and installation of the IWB to coincide with the purchase of six other IWBs in the school, Jenny's project necessitated her only reviewing and bookmarking valuable websites. This was a major source of frustration for Jenny as it was towards the conclusion of her project that she was able to use her bookmarked resources. Jenny's grant was not associated with this study in any way and her project concluded in the previous year.

Jenny highlighted that although this was her second year of being a primary science specialist teacher and she had been using the IWB for 12-months, she felt that she was "still learning" about both the subject of science and how to incorporate the IWB. She explained how she found this challenging as she didn't feel that she had "a solid science teaching background" or feel that she was an expert at using an IWB. During the first individual and first group interviews, Jenny was asked to describe her vision of how she desired to use the IWB. Her response was consistent with her beliefs and teaching practice. For example, she commented:

The effective use of the IWB looks like the teacher playing the role as a facilitator. Students know how to use the IWB as well as the teacher so that students can direct and steer the lesson together quickly and easily. Sometimes students will be working at tables whilst others will be working in a small group using the IWB. ... The IWB has provided me with the ability to make learning much more visual and engaging for students. ... It has provided relief from me having to be the expert by making it easier for me to discuss the theory behind science concepts. This has led me to be more confident generally in the class except when the technology isn't working (Individual Interview 1).

I believe the IWB is important to help students grasp concepts and support students to work in groups on hands-on tasks. ... The research I did last year showed that students loved interactive games. Students felt that they learnt best when these matched the practical handson activities and other websites that I showed them. The IWB is a fun device but it doesn't really help students' learning unless there is this alignment. ...The IWB has become an integral part of my teaching (Group Interview 1).

These comments suggest that Jenny's vision for the use of IWBs in primary science is aligned with current academic research about the affordances of IWB tools to assist teachers in producing and 
engaging students with multi-modal representations in the science classroom. The IWB can support a range of multimodal representation types including verbal, graphic, tabular, mathematical, pictorial and kinaesthetic (Murcia, 2010). This is important because new scientific understandings are generated through multiple representations of ideas, affective responses and evidence-based judgments (Tytler, 2007). It is argued that greater emphasis is required on meta-cognitive practices and how students construct meanings and understandings in order to expand their view of science as being more than simply content to be practised and remembered (Tytler, 2007). Furthermore, the Australian curriculum describes that students will develop their science inquiry skills through the use of digital technologies to observe, measure and record observations, construct and use a range of representations, and communicate ideas, findings and solutions to problems using digital technologies as appropriate (ACARA, n.d.).

Jenny valued the use of digital resources such as video clips and games in science to visually represent concepts. The use of these types of resources aligns to the first two ways of promoting interactivity identified by Beauchamp and Kennewell (2008). These authors identify three main ways of interactivity. Firstly, the IWB can be used as the object of interaction where resources such as a video clip provide a collective focus of reference. Secondly, the IWB can be used to promote interactivity as a participant in interaction through the use of quizzes or games that provide immediate feedback. Thirdly, the IWB can be used as a tool for interaction to support the pursuit of learning goals such as constructing a concept map to promote interpretation, discussion and development (Beauchamp \& Kennewell, 2008). Jenny demonstrated the third way of promoting interactivity during both classroom observations, where she had students revise and extend their conceptual understandings of animal classifications through drag-anddrop activities using the native IWB software (a flip chart).

During the first 3 months of the study it appeared that Jenny was approaching what Hooper and Rieber (1995) describe as a 'breakthrough' in her practice as she was reliant on the technology and identified her role as supporting and facilitating students to construct and shape their own knowledge using it to mediate interactions. Similarly, Jenny's actions and reflections about her practice were to use the IWB as the focal point of students' attention to illustrate, develop and test discreet concepts. This level of interactivity is also characteristic of the interactivity stage of development described by Glover, Miller, Averis, and Door (2004). Characteristic of this middle stage of development, "the IWB is fully integrated into teaching and learning but its full potential has not been developed" (p. 28). Moreover, teachers occasionally lose confidence in use of the technology. However, they show evidence of searching for new approaches and opportunities to learn from other teachers.

Given that two years is approximately the amount of time identified for teachers to begin changing their teaching practice to make best use of IWBs (Lewin et al., 2008; Somekh \& Haldane, 2006), it was anticipated that by the end of the project, Jenny would describe concerns characteristic of the stages of concern associated with impact concerns. However, these higher-level concerns were not evident throughout the project and this stimulated investigation into why this may have been the case using the theoretical framework of activity theory.

In terms of the stages of concern, Jenny's dialogue and actions during the initial stages of the project suggested alignment with the characteristics of stage 4 (task concerns) as she was feeling confident about her teaching practice with the IWB and becoming focused on issues related to efficiency, organisation, management and time. For example, when asked about how the IWB had influenced her practice, Jenny described how the IWB provided her with valuable support because she was able to keep her lessons focused on the topic and engage students in semi-autonomous, whole class learning with interactive resources. She commented:

Once I got the board I actually felt some relief because I thought it took away some of the 'having to be the expert'. ... Suddenly, I felt some pressure release off me because of what it could offer. Perhaps it was a bit of a gimmick. ... I certainly felt some degree of relief because of the lack of support you can have with science or a specialist teaching role because they [students] are doing their own thing. I felt it was almost like half a person worth of support. ... In the beginning you are not always on the topic as much as you could be. It's just that you have found a good web site and it's quite entertaining or you know it will interest students so you introduce that (Individual interview 1). 
Four themes emerged during the study, which indicated that Jenny was experiencing difficulty developing her practice using the IWB due to concerns and tensions in her activity system. The tensions and concerns that were revealed using the theoretical frameworks of the stages of concern and activity theory are now discussed as four themes.

\section{Theme 1: Technical difficulties}

During the first two individual interviews, Jenny was asked what she enjoyed and disliked about teaching, and describe changes that had occurred since our previous interview. Consequently, she described three main tensions related to technical difficulties with the use of technology. These tensions were not specific to the use of the IWB but to the use of peripheral tools used in conjunction with it.

The first two tensions are related and became evident in the first individual interview when Jenny commented:

I have spent many hours finding fabulous websites and putting them in my favourites whilst using my laptop at home until late at night. Then, when my laptop was replaced with a new one, all of my favourites vanished! Then I started using del.icio.us but I found it quite hard because I can't put things into folders (Individual Interview 1).

This comment suggests two tensions in Jenny's activity system. The first tension can be illustrated in Jenny's activity system as a primary tension within the node of tools and is associated with the loss of Jenny's favourite bookmarks on her new laptop and the inability to transfer these easily into her del.icio.us account when she eventually managed to retrieve them. The second related tension can be illustrated as a tension between the nodes of tools and subject. This tension emerged when Jenny described how she felt about the need to change her practice of using favourites and adopt a new more efficient practice of using the social bookmarking tool del.icio.us.

These tensions highlight the importance of professional development for teachers about efficient practices for the organisation and management or Internet websites. This is particularly important given that the use of the Internet is a valuable tool for use with the IWB. Outdated strategies to manage favourite websites are no longer efficient given the evolution of cloud based computing (Johnson, Smith, Willis, Levine, \& Haywood, 2011) and the necessity to use multiple computers that are regularly upgraded. Social bookmarking tools like del.icio.us or Diigo are effective strategies to enable teachers to manage their favourite websites from any computer connected to the Internet and share these easily with others. Unlike the use of favourites, social bookmarking organises websites using tags rather than folders.

A third tension was identified related to the theme of technical difficulties associated with Jenny's inability to access resources. This tension emerged during the second individual when Jenny commented:

We upgraded servers and laptops and the technician here left for a well-paying job. I want to advance my practice but it's not a smooth path. ... At home, I can access anything. If I want to use a video and I see a really pertinent one to use as a stimulus and visual illustration of a concept - I have to write to the principal to get the website unblocked so that I can access it. At the moment I can't access any video and I don't see when it's going to be happening. It's an old way of thinking which is to release one website at a time. We need new software installed on the server to enable video streaming. It's quite frustrating (Individual Interview 2).

This third tension in Jenny's activity system can be illustrated as a tension between the nodes of rulessubject-tools-division of labour. The tension is associated with the compulsory requirement that the school filter all Internet traffic using the Department of Education and Children's Services' software so as to minimise students being exposed to undesirable content. This system is administered externally; however each school appoints an administrator who is able to override specific websites if deemed appropriate. At Kingsford Primary School, Jenny is required to write to the Principal to apply for specific websites to be released from the filtering system. Hence, this 'rule' and the division of labour prevent Jenny from easily managing her access to pertinent visual learning resources for her classes when she needs them. In particular, any websites associated with games cannot be accessed. 
During her second individual interview, Jenny reflected on the impact of these three main tensions on her practice and remarked: "My learning journey would have been so much easier if the technology was available in the optimum way that I wanted - if it continued to work as it should. It's been quite hard and very frustrating" (Individual Interview 2).

\section{Theme 2: Professional isolation}

Throughout the project Jenny was asked a range of questions related to the digital resources that she was using on the IWB and how she planned her science lessons. This prompted her to describe two main tensions related to her professional isolation as the only specialist science teacher in the school. These tensions related to her expressed feelings of being without support from colleagues when sharing the workload for planning her lessons and her unique teaching context.

This first tension in Jenny's activity system associated with the theme of professional isolation from colleagues was recurrent in all interviews. This tension in Jenny's activity system can be illustrated using activity theory as situated between the nodes of subject and division of labour. In particular, Jenny identified that support for co-planning with colleagues would be valuable for her professional learning especially in terms of sharing the workload with other teachers who have an interest in science and who are willing to share valuable resources and practices. For example, Jenny stated:

There is a lot of great stuff out there but it takes a lot of time to investigate and because I am the only science person, I am not sharing with anyone and have to do all of the work on my own. ... I feel like I am out on a limb. ... The Principal is really into getting teachers working together and collaborating. ... The co-planning arrangements with colleagues does not help me. The Principal is trying to encourage the teacher-librarian, the PE [physical education] specialist and I to get together. We listen but do not help each other because we all have a different curriculum focus and interests. You might say that it's support but its not (Individual Interview 2).

The second tension in Jenny's activity system related to the theme of professional isolation can be illustrated between the nodes of community-tools-subject. This tension emerged in the first individual interview when Jenny explained that she had unique professional development needs compared to other teachers in the school. Specifically, she expressed her desire to focus on efficiently managing websites and making use of multimodal resources such as video, games and podcasts to help students grasp scientific concepts. She explained that she didn't see value in the Principal's insistance that all teachers attend workshops to learn the basic technical skills of the IWB and create 'flip charts' to become recognised as a Centre of Excellence for a specific manufacturer. Jenny described that she was concerned that this would encourage teachers to simply deliver content to students rather than support students to construct meanings and understandings through practical 'hands-on' learning activities. The Principal believed the creation of 'flip charts' would compel teachers to connect their technical design of interactive IWB lessons with their recent professional learning focused on high quality pedagogy.

During the first classroom observation and second individual interview, Jenny appeared to have made a noticeable shift in her attitude towards 'flip charts' compared to her first individual interview. She also was interested in learning from colleagues about new IWB software tools and techniques that she could add to her repertoire. In particular, she was concerned about "falling into habits" of only using the same limited skills and described learning about flip charts as a case of "use it or lose it" referring to the need for regular practice and application of skills so that they become an integral part of new practice. Whereas Jenny previously resisted the idea of time dedicated to learning IWB software skills, Jenny now suggested that more was needed for staff to share ideas for using new tools and techniques on a regular basis. This change indicates that Jenny was focused on stage 4 of the stages of concern and conscious of the need to increase her technical skills and fluency to improve her use of the IWB as a tool for interaction to support the achievement of learning goals.

Towards the conclusion of the project, after receiving training on the technical aspects of how to create flip charts, Jenny recognised their potential to save her time by not having to write lesson instructions on the whiteboard for each class and using them at the start of lessons to revise students' prior knowledge of the content focus from the previous lesson. It appeared that Jenny had resolved the tension for this theme 
and was aware that increasing her technical skills using flip charts was a strategy to increase the quality of her teaching by linking valuable visual resources together with other lesson resources like a script (Lewin, Somekh, \& Steadman, 2008). Specifically, Jenny, reflected:

I really do like flip charts now. I didn't see the purpose of them in the beginning but now I think they are fantastic. It took a long time to learn how to use the full range of IWB tools. In the beginning I used to play a lot of games and get excited. Now I feel that everything I do should be put straight into a flip chart (Pair Interview).

During the pair interview where participants were required to reflect and share their video taped classroom observation with each other, it appeared that Jenny showed indications of a higher level of concern related to the impact of her whole class use of the IWB on students. In particular, she was interested in learning how her interview partner wanted to replace a whole class teaching approach using the IWB with a small group work as the teacher believed this would increase student interactivity and therefore impact positively on students' learning. Jenny quickly dismissed this as impractical in her specialist lessons; especially when she didn't have access to other computers and valued practical work with concrete materials. However, she later reflected on how she could modify her approach:

What I tend to do is let those students that have finished their work, come and sit on the floor to play a game with me on the IWB. It is my laptop and I don't want it to break. ... I should actually try just letting go of students using the IWB without me (Pair Interview).

This concern is further evidence of a tension between the nodes of community-tools-subject for this theme as Jenny dismissed using the IWB to support small group work as suggested by her colleague. It is interesting to note that the use of small group work using the IWB was part of the vision that Jenny described at the start of the project. Thus, it appears Jenny may have experienced some form of cognitive dissonance as she was aware of the value of standing back to allow students to use the IWB however she also felt there were underlying issues constraining her ability to do this. These can be explained in part due to a student behaviour tension described in the next theme.

\section{Theme 3: Student behaviour}

Despite Jenny's evaluation of the IWB as having a positive impact on her teaching, two major tensions became evident in her activity system related to student behaviour. These were described in all interviews, elicited by asking Jenny about her role as a specialist science teacher and her level of control of student interactivity using the IWB.

The first tension related to the learning approach adopted in science lessons. The second tension related to students' expectations of teachers' technical skills and efficiency using the IWB. Both tensions can be illustrated as a tension between the nodes of community-tools-subject and are associated with the fourth stage of "task" oriented concerns as Jenny's aim was to regulate her lessons so that they were efficient, organized and well managed in terms of time. Concerning the first tension, Jenny described how students found it difficult to work collaboratively on group practical activities and this was a major source of student behaviour management concerns. She explained:

In some classrooms, students don't do a lot of group work and are seated in rows but in the science room students are suddenly thrown into groups of six in a large room and that is totally different to what they experience most of the time. Learning becomes a lot more social and requires more than just individual thinking (Individual Interview 1).

The second tension related to students' expectations of Jenny's technical skills and efficiency using the IWB. During interview two, Jenny explained that she had decided to change her attitude about the need for teachers to be more knowledgeable than students so that she could embrace opportunities to learn new IWB skills from students. However, this wasn't easy as it required allowing students to show her how to do something and this was a cause of behaviour disruptions at times. She remarked:

Teachers always like to be at least a couple of steps ahead but technology is a new thing where students don't expect or don't want the teacher to be ahead if they feel like they are 
pretty good at the technology themselves. ... There is this equalising thing. Teachers have to give up a little bit and the students can show teachers how to do something. ... Students have taught me some fantastic teaching hints and this is a growth movement. Sometimes a student will call out what I should do and that's good if only one student does it. But it's just awful when they are all yelling at me at the same time. Students know more than me and I need to say - let it go - you can take on what they know - that's a new thing (Individual Interview 2).

To resolve student behaviour problems when using the IWB, Jenny found it best to ensure that all Internet websites and files were quickly and easily located. She remarked:

I know I panic and think 'where is that? And you hear the students' voices getting louder and louder as they get really impatient. Whereas when the same thing happens in their regular classroom, there can be a more relaxed response like, 'oh, well, I will go back later and try again' but I can't do that in science lessons due to the intense time constraints (Individual Interview 1).

\section{Theme 4: Time constraints}

A major tension was evident in Jenny's activity system related to time constraints and this can be illustrated as a tension between the nodes of rules-subject-division of labour. This tension became evident in the first individual interview when Jenny responded to questions related to the duration of her lessons and how she planned the curriculum for students in different year levels. In particular, Jenny expressed concern over a lack of time to fit everything into the curriculum and found that she was doing a lot of the work whilst students observed her performance. She explained that weekly lessons for the Reception to Year 2 students were 60-minutes in duration (or two, 30-minutes lessons) whilst the lessons for the Year 3-7 students were 90-minutes. This allocation was based on the non-instructional release time requirement for teachers. Jenny commented:

... Lessons are designed to be one-off for simplicity so that there is no need to follow through with activities so that the students and I don't forget. It is a challenge. By the end of last year it felt like an assembly line and the students were looking at me like 'we're here and ready. What are you going to perform for us today? (Individual Interview 1).

Throughout the project Jenny attempted to meaningfully connect what happens "at the board, on the desk, [and] in the head" (Miller, Glover, \& Averis, 2008, p. 3). Specifically, she described how she planned her lessons to include: (1) an introduction or revision of scientific concepts; (2) instructions for students on how to complete related practical activities in small groups; (3) a conclusion that included sharing and discussion of the results. The IWB was intended to be an integral part of all parts of the lesson. However, during both classroom observations, it was evident that implementing this plan was a challenge as there was insufficient time to complete all parts of the lesson. Most of the time spent during both classroom observations was focused on the use of flip charts on the IWB to support the discussion and development of scientific concepts using drag and drop activities and instructions about how to conduct practical activities and record the results. As a result, this left insufficient time for the last two parts of the lesson. When reflecting on her videotaped lesson, Jenny remarked:

I was looking at my lesson cringing at the amount of time that I was out the front talking and controlling. I really think there has to be a better way. I guess it just has to be faster paced and less sitting and talking. It seemed awfully slow watching it (Pair Interview).

Jenny's comment stimulated a response from her pair interview partner who was concerned that a faster paced lesson may result in some students being left behind. The fact that Jenny was more concerned about fitting everything into her lesson and less concerned about the impact on student learning outcomes, suggests that she was experiencing stage 4 concerns about the use of the IWB. Thus, Jenny appeared more concerned about the organisation and management of time than about higher-level concerns related to the impact on student learning. Alternatively, Jenny's "cringing" when viewing her lesson strengthens the earlier suggestion that she may be experiencing a form of cognitive dissonance (see Theme 3). 
Specifically, she appears to want to control the lesson to fit everything in and keep students focused on the topic as there are limited opportunities to connect lessons together in a meaningful series.

\section{Conclusion}

This paper utilised the theoretical frameworks of activity theory and the stages of concern to investigate the behavioural and affective domains of change associated with a specialist science teacher's use of an IWB in a primary school. The findings of this study support previous research, which contends that technology has no agency and does not in itself, have a positive transformative effect on classroom teaching and learning. IWBs are only as effective as the pedagogy that accompanies it. To maximise the potential of IWBs to mediate learning interactions through the creation of shared dialogic learning spaces within which co-constructed knowledge building can take place, necessitates supporting teachers to acquire a significant amount of sustained experience where they are supported to apply their technical and pedagogical professional learning.

This study has contributed to the research field by highlighting that the emotional aspects of change are an important and integral part of science pedagogical reform. Teachers are critical agents in mediating the integration of the IWB into their pedagogical subject knowledge and it is crucial that tensions and concerns within a teacher's activity system are identified and resolved to facilitate innovation and sustainable pedagogical change. If teachers feel frustrated by technical difficulties, professionally isolated from supportive colleagues, preoccupied with managing students' behaviour and constrained by rigid timetabling, it is possible that their practice will not develop a focus on 'impact' concerns about how IWBs may affect students, colleagues and future work. Hence, there is a risk that the considerable investment in IWBs in schools will be ineffectual.

This paper identified the potential of IWBs to enhance learning interactions in a shared dialogic space and that research has suggested that non-expert peer mentoring professional development models are highly effective in supporting teachers to modify their practices to exploit the affordances of IWBs. The findings of this study highlighted the sense of professional isolation that can be experienced by specialist science teachers. Therefore, it is recommended that school leaders support specialist science teachers to work in collaboration with regular class teachers within their school, as well as other specialist teachers beyond their school, on the implementation of the science curriculum using relevant digital resources and the use of IWBs to support students' semi-autonomous learning. This collaboration should be continuous and involve shared responsibility for the achievement of curriculum outcomes. It should also enable students to make meaningful connections between their learning in specialist science lessons and other learning areas. At the conclusion of this study, the school adopted a peer mentoring model involving Jenny supporting regular class teachers to implement the Primary Connections science and literacy resources (Australian Academy of Science, 2012b). However, this model was only possible due to short term funding provided by the initiative called Strategic Directions for Science and Mathematics in South Australian Schools (Government of South Australia, 2012) at the school level.

\section{References}

ACARA. (n.d.). Australian curriculum online. Available from http://www.australiancurriculum.edu.au/Home

Armstrong, V., Barnes, S., Sutherland, R., Curran, S., Mills, S., \& Thompson, I. (2005). Collaborative research methodology for investigating teaching and learning: The use of interactive whiteboard technology. Educational Review, 57(4), 457-469.

Australian Academy of Science. (2012a). Primary Connections and science education pedagogical reform. In K. Skamp (Ed.), Teaching primary science: Trial-teacher feedback on the implementation of Primary Connections and the $5 E$ model. Retrieved from http://www.science.org.au/primaryconnections/research-and-evaluation/images/tps_fullreport.pdf

Australian Academy of Science. (2012b). Primary Connections: Linking science with literacy. Retrieved from http://science.org.au/primaryconnections/ 
Beauchamp, G. (2004). Teacher use of the interactive whiteboard in primary schools: Towards an effective transition framework. Technology, Pedagogy and Education, 13(3), 327-348.

Beauchamp, G. (2006). New technologies and 'new teaching': A process of evolution? In R. Webb (Ed.), Changing teaching and learning in the primary school (pp. 81-91). Open University Press.

Beauchamp, G., \& Kennewell, S. (2008). The influence of ICT on the interactivity of teaching. Education and Information Technologies, 13(4), 305-315.

Bennett, S., \& Lockyer, L. (2008). A study of teachers' integration of interactive whiteboards into four Australian primary school classrooms. Learning, Media and Technology, 33(4), 289-300.

Campbell, C., \& Kent, P. (2010). Using interactive whiteboards in pre-service teacher education: Examples from two Australian universities. Australasian Journal of Educational Technology, 26(4), 447-463.

Centre for Activity Theory and Developmental Work Research. (2003). Cultural-historical activity theory. Retrieved from http://www.edu.helsinki.fi/activity/pages/chatanddwr/chat/_

Cole, M., \& Engstrőm, Y. (1993). A cultural-historical approach to distributed cognition. In G. Salomon (Ed.), Distributed cognitions: Psychological and educational considerations. New York: Cambridge University Press.

Dawson, P. (2010). Networked interactive whiteboards: Rationale, affordances and new pedagogies for regional Australian higher education. Australasian Journal of Educational Technology, 26(4), 523533.

Divaharan, S., \& Koh, J. H. L. (2010). Learning as students to become better teachers: Pre-service teachers' IWB learning experience. Australasian Journal of Educational Technology, 26(4), 553-570.

Engestrom, Y. (1987). Learning by expanding: An activity-theoretical approach to developmental research. Helsinki: Orienta-Konsultit.

Engestrom, Y. (1993). Developmental studies of work as a test bed of activity theory In S. Chaiklin \& J. Lave (Eds.), Understanding practice: Perspectives on activity and context (pp. 64-103). Cambridge: Cambridge University Press.

Fuller, F. (1969). Concerns of teachers: A developmental conceptualization. American Educational Research Journal, 6(2), 207-226.

Gay, G., Rieger, R., \& Bennington, T. (2002). Using mobile computing to enhance field study. In T. Koschmann, R. Hall, \& N. Miyake (Eds.), CSCL 2: Carrying forward the conversation. Mahwah, NJ: Lawrence Erlbaum.

Gillen, J., Staarman, J. K., Littleton, K., Mercer, N., \& Twiner, A. (2007). A 'learning revolution'? Investigating pedagogic practice around interactive whiteboards in British primary classrooms. Learning, Media and Technology, 32(3), 243-256.

Glover, D., \& Miller, D. (2001). Running with technology: The pedagogic impact of the large-scale introduction of interactive whiteboards in one secondary school. Journal of Information Technology for Teacher Education, 10(3), 257-275.

Glover, D., Miller, D., Averis, D., \& Door, V. (2004). Leadership implications of using interactive whiteboards: Linking technology and pedagogy in the management of change. Management in Education, 18(5), 27-30. 
Glover, D., Miller, D., Averis, D., \& Door, V. (2007). The evolution of an effective pedagogy for teachers using the interactive whiteboard in mathematics and modern languages: An empirical analysis from the secondary sector. Learning, Media and Technology, 32(1), 5-20.

Gobbo, C., \& Girardi, M. (2001). Teachers' beliefs and intergration of information communications technology in italian schools. Journal of Information Technology for Teacher Education, 10(1\&2), 63-85.

Government of South Australia. (2012). Strategic Directions for Science and Mathematics in South Australian Schools. Retrieved from http://www.scimas.sa.edu.au/scimas/pages/PMSS/Intro/

Green, H., Facer, K., Rudd, T., Dillon, P., \& Humphreys, P. (2005). Personalisation and digital technologies. Bristol, U.K.: Futurelab.

Hackling, M., Peers, S., \& Prain, V. (2007). Primary connections: Reforming science teaching in Australian primary schools. Teaching Science, 53(3), 12-16.

Hall, G. (2010). Technology's Achilles heel: Achieving high-quality implementation. Journal of Research on Technology in Education, 42(3), 231-253.

Hall, G., \& Hord, S. (2006). Implementing change: Patterns, principles and potholes (2nd ed.). Boston: Allyn and Bacon.

Hennessy, S. (2006). Integrating technology into the teaching and learning of school science: A situated perspective on pedagogical issues in research. Studies in Science Education, 42(1), 1-48.

Higgins, S., Beauchamp, G., \& Miller, D. (2007). Reviewing the literature on interactive whiteboards. Learning, Media and Technology, 32(3), 213-235.

Holmes, K. (2009). Planning to teach with digital tools: Introducing the interactive whiteboard to preservice secondary mathematics teachers. Australasian Journal of Educational Technology, 25(3), 351365.

Hooper, S., \& Rieber, L. (1995). Teaching with technology. In A. Ornstein (Ed.), Teaching: Theory into practice (pp. 154-170). Needham Heights, MA: Allyn and Bacon.

Illinois Institute of Design. (2007). Schools in the digital age. Illinois: Illinois Institute of Technology.

Jang, S. J. (2010). Integrating the interactive whiteboard and peer coaching to develop the TPACK of secondary science teachers. Computers \& Education, 55(4), 1744-1751.

Jang, S. J., \& Tsai, M. (2012). Exploring the TPACK of Tiawanese elementary mathematics and science teachers with respect to interactive whiteboards. Computers \& Education, 59(2), 327-338.

John, P., \& Sutherland, R. (2005). Affordance, opportunity and the pedagogical implications of ICT. Educational Review, 57(4), 405-413.

Jones, A., \& Vincent, J. (2010). Collegial mentoring for effective whole school professional development in the use of IWB technologies. Australasian Journal of Educational Technology, 26(4), 477-493.

Johnson, L., Smith, R., Willis, H., Levine, A., \& Haywood, K. (2011). The 2011 horizon report. Austin, Texas.

Kearney, M., \& Schuck, S. (2008).Exploring pedagogy with interactive whiteboards in Australian schools. Australian Educational Computing 23(1), 8-14.

Kennewell, S., Tanner., Jones, S., \& Beauchamp, G. (2008). Analysing the use of interactive technology to implement interactive teaching. Journal of Computer Assisted Learning, 24(1), 61-73. 
Kennewell, S., Tanner, H., Jones, S., Parkinson, J., Norman, M., \& Meiring, L. (2005). Characterising interactivity in the teaching of different subjects using ICT in secondary schools, Symposium on Interactive Teaching and Interactive Technologies, BERA. Pontypridd: University of Glamorgan.

Kent, P. (2004). E-teaching and interactive whiteboards. The Richardson experience. The Practising Administrator, 26(1). 14-16.

Kershner, R., Mercer, N., Warwick, P., \& Staarman, J. (2010). Can the interactive whiteboard support young children's collaborative communication and thinking in classroom science activities? International Journal of Computer-Supported Collaborative Learning, 5(4), 359-383.

Kitson, L. (2011). Reconceptualising understandings of texts, readers and contexts: One English teacher's response to using multimodal texts and interactive whiteboards. English in Australia, 46(3), 76-86.

Lai, H.-J. (2010). Secondary school teachers' perceptions of interactive whiteboard training workshops: A case study from Taiwan. Australasian Journal of Educational Technology, 26(4), 511-522.

Lee, M. (2010). Interactive whiteboards and schooling: The context. Technology, Pedagogy and Education, 19(2), 133-141. http://dx.doi.org/10.1080/1475939X.2010.491215

Lee, M., \& Boyle, M. (2003). The educational effects and implications of the interactive whiteboard strategy of Richardson Primary School - A brief review. Retrieved from http://www.richardsonps.act.edu.au

Levy, P. (2002). Interactive whiteboards in learning and teaching in two Sheffield schools: A developmental study: Department of Information Studies, Sheffield University.

Lewin, C., Somekh, B., \& Steadman, S. (2008). Embedding interactive whiteboards in teaching and learning: The process of change in pedagogic practice. Education and Information Technologies, 13(4), 291-303.

Maher, D., Phelps, R., Urane, N., \& Lee, M. (2012). Primary school teachers' use of digital resources with interactive whiteboards: The Australian context. Australasian Journal of Educational Technology, 28(1), 138-158.

Miller, D., Glover, D., \& Averis, D. (2008). Enabling enhanced mathematics teaching with interactive whiteboards: National Centre for Excellence in the Teaching of Mathematics, Keele University, UK.

Mildenhall, P., Swan, P., Northcote, M., \& Marshall, L. (2008). Virtual manipulatives on the interactive whiteboard: A preliminary investigation. Australian Primary Mathematics Classroom, 13(1), 9-14.

Mishra, P., \& Koehler, M. (2006). Technological pedagogical content knowledge: A new framework for teacher knowledge. Teachers College Record, 108(6), 1017-1054.

Mitchell, J., Hunter, J., \& Mockler, N. (2010). Connecting classrooms in rural communities through interactive whiteboards. Australasian Journal of Educational Technology, 26(4), 464-476.

Moersch, C. (2011). Levels of Teaching Innovation (LoTi Framework). Retrieved from http://www.loticonnection.com/index.php/more/frameworks/20-loti-framework

Murcia, K. (2010). Multi-modal representations in primary science: What's offered by interactive whiteboard technology. Teaching Science, 56(1), 23-29.

Murcia, K., \& Sheffield, R. (2010). Talking about science in interactive whiteboard classrooms. Australasian Journal of Educational Technology, 26(4), 417-431.

Naisbitt, J. (1984). Megatrends. London: Futura. 
Northcote, M., Mildenhall, P., Marshall, L., \& Swan, P. (2010). Interactive whiteboards: Interactive or just whiteboards? Australasian Journal of Educational Technology, 26(4), 494-510.

QSR International (2008). NVivo qualitative data analysis software. QSR International Pty Ltd. Retrieved from http://www.qsrinternational.com/products_nvivo.aspx

Rudd, T. (2007). Interactive whitebords in the classroom. London, UK: Futurelab.

Schuck, S., \& Kearney, M. (2007). Exploring pedagogy with interactive whiteboards. Sydney: University of Technology.

Smith, H., Higgins, S., Wall, K., \& Miller, J. (2005). Interactive whiteboards: Boon or bandwagon? Journal of Computer Assisted Learning, 21, 91-101.

Somekh, B. (2007). Pedagogy and learning with ICT: Researching the art of innovation. London: Routledge.

Somekh, B., \& Haldane, M. (2006). How can interactive whiteboards contribute to pedagogic change? Learning from case studies in English primary schools, Imagining the Future for ICT and Education conference. Alesund, Norway.

State of NSW, Department of Education and Training (2006). Quality teaching in NSW public schools: A classroom practice guide. Professional Learning and Leadership Development Directorate, Ryde: NSW

Strauss, A. \& Corbin, J. (1998). Basics of qualitative research: techniques and procedures for developing grounded theory. Thousand Oaks: Sage Publications.

Swan, P., \& Marshall, L. (2010). Revisiting mathematics manipulative materials. Australian Primary Mathematics Classroom, 15(2), 13-19.

Sweeney, T. (2010). Transforming pedagogy through interactive whiteboards: Using activity theory to understand tensions in practice. Australian Educational Computing, 24(4), 28-34.

Tytler, R. (2007). Australian education review. Re-imaging science education: Engaging students in science for Australia's future: Australian Council for Educational Research.

Underwood, J., Baguley, T., Banyard, P., Dillon, G., Farrington-Flint, L., Hayes, M., Le Geyt, G.,, \& Selwood, I. (2010). Understanding the impact of technology: Learner and school level factors. BECTA. Retrieved from http://oro.open.ac.uk/34529/1/Understanding\%20the\%20impact\%20of\%20technology.pdf

Vincent, J., \& Jones, A. (2008). Using models for understanding pedagogical change in a technology environment: A case study of IWB implementation in a secondary school. Australian Educational Computing. 23(2), 32-37.

Warwick, P., Mercer, N., Kershner, R., \& Kleine Staarman, J. (2010). In the mind and in the technology: The vicarious presence of the teacher in pupils' learning of science in collaborative group activity at the interactive whiteboard. Computers and Education, 55(1), 350-362.

Winzenried, A., Dalgarno, B., \& Tinkler, J. (2010). The interactive whiteboard: A transitional technology supporting diverse teaching practices. Australasian Journal of Educational Technology, 26(4), 534552.

Yelas, J., \& Engles, P. (2010). Project ACTIVate: Innovations from New Zealand. Australasian Journal of Educational Technology, 26(4), 432-446. 
Zevenbergen, R., \& Lerman, S. (2007). Pedagogy and interactive whiteboards: Using an activity theory approach to understand tensions in practice. Paper presented at the 30th annual conference of the Mathematics Education Research Group of Australasia, Adelaide. Retrieved from http://www.merga.net.au/documents/RP812007.pdf

Zevenbergen, R., \& Lerman, S. (2008). Learning environments using interactive whiteboards: New learning spaces or reproduction of old technologies? Mathematics Education Research Journal, 20(1), 108-126.

Corresponding author: Trudy Sweeney, trudy.sweeney@flinders.edu.au

Australasian Journal of Educational Technology (C) 2013.

Please cite as: Sweeney, T. (2013). Understanding the use of interactive whiteboards in primary science. Australasian Journal of Educational Technology, 29(2), 217-232. 